\title{
Hemodilution does not alter the coronary vasodilating effects of endogenous or exogenous nitric oxide
}

\author{
[L'bémodilution ne modifie pas les effets vasodilatateurs coronariens de l'oxyde \\ nitrique endogène ou exogène]
}

George J. Crystal PhD, ${ }^{*} \dagger \neq §$ Mohammad El-Orbany MD, ${ }^{*}$ Xiping Zhou MD, ${ }^{*} \ddagger$ M. Ramez Salem MD, ${ }^{*} \ddagger$ Song-Jung Kim $\mathrm{PhD}^{*}+\$$

Introduction: It is well known that hemoglobin is a scavenger of nitric oxide (NO). The present study used a canine model to test the hypothesis that acute normovolemic hemodilution $(\mathrm{ANH})$ affects NO-mediated coronary vasodilation.

Methods: Studies were performed in 18 open-chest, anesthetized dogs. In Series I, the contribution of endogenous NO to coronary vasodilatation during $\mathrm{ANH}$ with $5 \%$ dextran-40 (reduction in hematocrit by $50 \%$ ) was assessed. This was accomplished by comparing myocardial blood flow (MBF; radioactive microspheres) in the left anterior descending (LAD) region, which was treated with the $\mathrm{NO}$ synthase inhibitor, $\mathrm{N}^{\mathrm{G}}$-nitro-Larginine methyl ester (L-NAME), to that in the circumflex (control) region. In Series 2, the LAD was perfused via a controlledpressure extracorporeal system with coronary blood flow (CBF) measured with an ultrasonic, transit-time flow transducer. The dose-dependent increases in CBF caused by acetylcholine $(\mathrm{ACh})$, which releases endogenous NO from the vascular endothelium, and sodium nitroprusside (SNP), which provides exogenous $\mathrm{NO}$, were compared before and during $\mathrm{ANH}$.

Results: Acute normovolemic hemodilution caused similar (approximately twofold) increases in MBF $(P<0.0 \mathrm{I})$ in the absence and presence of L-NAME, and it did not affect the dose-related increases in CBF caused by ACh and SNP.

Conclusions: Series I: under baseline conditions, hemoglobin in red blood cells does not limit the coronary vasodilatation resulting from tonic release of $\mathrm{NO}$; $\mathrm{NO}$ does not mediate coronary vasodilation during $\mathrm{ANH}$. Series 2: ANH does not influence the coronary vasodilating effects of increased levels of $\mathrm{NO}$, whether due to endogenous release ( $\mathrm{ACh}$ ) or infusion of an NO donor (SNP).

CAN J ANESTH 2008/55:8/pp 507-514

Introduction : Le fait que l'hémoglobine puisse désactiver l'oxyde nitrique (NO) est bien connu. Cette étude s'est servi d'un modèle canin pour tester l'hypothèse que l'hémodilution normovolémique aiguë (ANH) affecte la vasodilatation coronarienne produite par l'oxyde nitrique.

Méthode : Les études ont été réalisées sur 18 chiens anesthésiés, à thorax ouvert. Dans la série $I$, nous avons évalué la contribution d'oxyde nitrique endogène à la vasodilatation coronarienne pendant une $\mathrm{ANH}$ avec du dextran-40 $5 \%$ (réduction de $50 \%$ de l'hématocrite). Pour ce faire, nous avons comparé le débit sanguin myocardique (MBF ; microsphères radioactives) dans la région de l'artère interventriculaire antérieure (LAD - left anterior descending), qui a été traitée avec l'inhibiteur de synthase d'oxyde nitrique, le $N^{G}$ nitro-L-arginine methyl ester (L-NAME), à celle de l'artère auriculoventriculaire (témoin). Dans la série 2, la LAD a été perfusée via un système extracorporel à pression contrôlée avec un débit coronarien (CBF) mesuré à l'aide d'un capteur ultrasonique de dé-

From the Department of Anesthesiology, ${ }^{*}$ and Section of Cardiology, $†$ Advocate Illinois Masonic Medical Center; and the Departments of Anesthesiology $\ddagger$ and of Physiology and Biophysics, $\$ \mathbb{S}$ University of Illinois College of Medicine, Chicago, Illinois, USA.

Address correspondence to: Dr. George J. Crystal, Department of Anesthesiology, Advocate Illinois Masonic Medical Center,

836 West Wellington Avenue, Chicago, IL 60657 USA. Phone: 773-296-5375; Fax: 312-296-5362; E-mail: gcrystal@uic.edu

This investigation was funded by the Department of Anesthesiology, Advocate Illinois Masonic Medical Center, Chicago, Illinois and by the Joan and Norman Chapman Family Foundation.

Present address: Dr. Mohammad El-Orbany, Department of Anesthesiology, Medical College of Wisconsin, Milwaukee, Wisconsin, USA.

Dr. Xiping Zhou, Department of Physiology, SooChow University, China.

The authors had no potential competing interests.

Accepted for publication March 3, 2008.

Revision accepted May 15, 2008. 
bit mesurant le temps de transit. Les augmentations de CBF liées à la dose provoquées par l'acétylcholine (ACh), qui libère de l'oxyde nitrique endogène de l'endothélium vasculaire, et par le nitroprussiate de sodium (SNP), qui fournit de l'oxyde nitrique exogène, ont été comparées avant et pendant l'ANH.

Résultats : L'hémodilution normovolémique aiguë a provoqué des augmentations similaires (environ deux fois) de MBF $(P<0,01)$ en l'absence et en présence de L-NAME, et cela n'a pas affecté les augmentations liées à la dose du CBF provoquées par l'ACh et le SNP.

Conclusion : Série I : dans des conditions de base, l'hémoglobine dans les érythrocytes ne limite pas la vasodilatation coronarienne résultant de la libération tonique d'oxyde nitrique ; l'oxyde nitrique ne joue pas de rôle vasodilatateur durant une ANH. Série 2 : L'ANH n'influence pas les effets vasodilatateurs coronariens de niveaux élevés d'oxyde nitrique, que ce soit en raison d'une libération endogène (ACh) ou d'une perfusion d'un donneur d'oxyde nitrique (SNP).

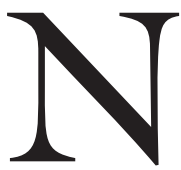
ITRIC oxide $(\mathrm{NO})$ is a free radical that is synthesized in endothelial cells from the amino acid L-arginine, in a reaction catalyzed by NO synthase (NOS) and triggered by rises in intracellular $\mathrm{Ca}^{++}$concentration ${ }^{1}$. Nitric oxide diffuses to the vascular smooth muscle cell, where it stimulates guanylate cyclase to catalyze the conversion of guanosine triphosphate to guanosine 3'-5'-cyclic monophosphate (cGMP), which has a vasorelaxing action. ${ }^{1}$

It is well known that free hemoglobin is an avid scavenger of NO. ${ }^{1}$ The close proximity of the endothelium to the millimolar concentrations of hemoglobin contained within the red blood cells (RBCs) was initially difficult to reconcile with the substantial evidence indicating that the NO-cGMP pathway plays a prominent role in modulating vasomotor tone in vivo. ${ }^{2}$ This evidence includes the increases in arterial blood pressure, resulting from vasoconstriction following systemic administration of NOS inhibitors, such as $\mathrm{N}^{\mathrm{G}}$-nitro-L-arginine methyl ester (L-NAME), ${ }^{3}$ and the ability of endothelium-dependent vasodilators that release endogenous $\mathrm{NO}$, such as acetylcholine (ACh) and bradykinin, to cause extensive vasodilation in various vascular beds, including the myocardium. ${ }^{4,5}$ The answer to this apparent paradox was found in studies that used in vitro methodologies and mathematical modeling to compare the NO scavenging capabilities of hemoglobin contained within the RBCs with that of free hemoglobin. ${ }^{6-9}$ These studies found that the physical compartmentalization of hemoglobin within the RBCs effectively limits the rate at which $\mathrm{NO}$ is consumed by hemoglobin, i.e., the rate of NO consumption by RBCs was up to 2,000 times slower than by an equivalent concentration of free hemoglobin.

The relatively low rate of NO consumption by hemoglobin contained in the RBCs does not preclude the possibility that this effect may be sufficient to play a physiological role in limiting NO bioavailability and NO-induced vasodilation. Previous studies have addressed this issue in the systemic circulation and in selected regional circulations, including the forearm, and the cerebral and gastric circulations, albeit with inconsistent results. ${ }^{10-15}$ To date, no attention has been paid to the coronary circulation.

The present study used a canine model to test the hypothesis that acute normovolemic hemodilution $(\mathrm{ANH})$ affects NO-mediated coronary vasodilation. This was accomplished using two experimental approaches. In the first approach (Series 1), we evaluated whether L-NAME could blunt the increases in myocardial blood flow (MBF) during ANH. Behind our studies was the following theory: If scavenging of $\mathrm{NO}$ by the RBCs was limiting NO bioavailabilty and $\mathrm{NO}$-mediated vasodilation under baseline conditions, ANH should reduce this effect, thus increasing NO availability to the vascular smooth muscle and causing coronary vasodilation. This would be reflected in an ability of L-NAME to blunt the increases in MBF during ANH. In the second approach (Series 2), we determined the ability of ANH to enhance the increases in coronary blood flow $(\mathrm{CBF})$ caused by release of endogenous $\mathrm{NO}(\mathrm{ACh})$ and by a donor of exogenous $\mathrm{NO}$, sodium nitroprusside (SNP).

\section{Methods}

\section{Canine preparation}

The investigation conforms to the "Guide for the Care and Use of Laboratory Animals", published by the US National Institutes of Health (NIH Publication No. 85-23, revised 1996). Experiments were performed on 18 conditioned mongrel dogs of either sex (weight range $2 \mathrm{l}-24 \mathrm{~kg}$ ). Anesthesia was induced with an intravenous bolus injection of thiopental, in a dose of $30 \mathrm{mg} \cdot \mathrm{kg}^{-1}$. After tracheal intubation, anesthesia was maintained by ventilation with $1.4 \%$ isoflurane in oxygen, which is 1.0 minimum alveolar concentration in the dog. ${ }^{16} \mathrm{PO}_{2}, \mathrm{PCO}_{2}$, and $\mathrm{pH}$ of arterial blood samples were measured electrometrically (model 413, Instrumentation Laboratories, Lexington, MA, USA). The volume and rate of the ventilator were set to maintain $\mathrm{PCO}_{2}$ between $35-40 \mathrm{mmHg}$ and $\mathrm{PO}_{2}$ above $250 \mathrm{mmHg}$. Sodium bicarbonate solution was given, as necessary, to correct metabolic acidosis. Hematocrit of blood samples was determined 
with a microcentrifuge. Core body temperature was monitored and maintained at $38^{\circ} \mathrm{C}$ with a heating pad, warmed intravenous fluids, and warming lights. Heparin, $400 \mathrm{U} \cdot \mathrm{kg}^{-1}$, was administered post-surgically, to prevent blood coagulation. Polyethylene cannulas were inserted into: 1) the thoracic aorta via the left femoral and right brachial arteries, for monitoring aortic blood pressure and for obtaining samples of arterial blood for analysis of gas composition; 2) the right femoral vein, for intravenous injections and infusions; and 3) the left femoral vein and right carotid artery, for exchange of whole blood with dextran solution. The anterior wall of the left ventricle was exposed through a left thoracotomy in the fourth intercostal space. Aortic pressure was measured with a Statham transducer (model P23ID, Gould, Cleveland, $\mathrm{OH}, \mathrm{USA}$ ) and averaged electronically. A permanent record of monitored hemodynamic parameters was obtained with a Gould recorder (model 2800S, Gould, Cleveland, OH, USA).

\section{Experimental protocols}

SERIES 1

EFFECT OF ANH IN PRESENCE AND ABSENCE OF L-NAME

The left anterior descending coronary artery (LAD) of 12 dogs was dissected free, just distal to its first major diagonal branch, and equipped with a non-cannulating ultrasonic transit-time flow transducer (Transonics Systems, Inc., Ithaca, NY, USA) to measure CBF. A silk ligature was placed loosely around the LAD to permit intermittent coronary occlusions for determination of zero flow, and for evaluation of coronary vasodilator reserve by analysis of reactive hyperemic responses. A small polyethylene cannula was inserted into the left atrium via the left atrial appendage for injecting radioactive microspheres to obtain measurements of MBF.

The dogs were randomly divided into two equal groups; Group 1, the NOS inhibition group $(n=6)$, and Group 2, the endothelium intact group $(n=6)$. The dogs were permitted to stabilize for at least $30 \mathrm{~min}$ following surgical preparation, before baseline measurements (hematocrit approximately 40\%) of MBF and other hemodynamic parameters were obtained. In Group 1, L-NAME was infused selectively into the LAD (4.5 $\mathrm{mg}$ over $15 \mathrm{~min})$ to inhibit NOS; the circumflex (CX) region served as a control. Effectiveness of L-NAME was verified from the increases in CBF, in response to intracoronary infusions of the endothelium-dependent vasodilator, ACh $\left(20 \mu \mathrm{g} \cdot \mathrm{min}^{-1}\right)$, and the endothelium-independent vasodilator, SNP $\left(80 \mu \mathrm{g} \cdot \mathrm{min}^{-1}\right) .{ }^{4}$ After post-L-NAME measurements of
MBF were obtained, ANH was produced by removing blood from the carotid artery at a rate of $20 \mathrm{~mL} \cdot \mathrm{min}^{-1}$, while replacing it with $5 \%$ dextran (molecular weight 40,000; American McGaw) pumped into the femoral vein at the same rate. When hematocrit had been decreased to a value $50 \%$ of baseline, the measurements of $\mathrm{MBF}$ were repeated.

In Group 2, the effect of ANH on MBF was evaluated without treatment of either the LAD or the CX region with $\mathrm{L}$-NAME. This was done to validate the use of the CX region as a control for the LAD region in Group 1. In Group 2, coronary vasodilator reserve was evaluated in the LAD bed under baseline condition and following $\mathrm{ANH}$; the ratio of the peak $\mathrm{CBF}$ was used during the reactive hyperemia following release of a 60 -sec occlusion to the baseline (preocclusion) $\mathrm{CBF} .{ }^{17,18}$

\section{SERIES 2}

EFFECT OF ANH ON ACh- AND SNP-INDUCED CORONARY VASODILATION

Additional studies were performed on six dogs to assess effect of ANH on ACh- and SNP-induced coronary vasodilation. An extracorporeal perfusion system containing an arterial blood reservoir was used to facilitate the intracoronary infusions of drugs and to ensure that coronary perfusion pressure was maintained constant at $80 \mathrm{mmHg}$. Coronary blood flow was measured with an in-line ultrasonic, transit-time flow transducer (Transonic Systems, Inc., Ithaca, NY, USA). The details of the coronary perfusion system have been previously presented. ${ }^{4}$

Under baseline conditions (after at least 30 min was allowed for recovery from surgical preparation), ACh and SNP in isotonic saline were infused separately into the LAD at 10,20 , and $40 \mu \mathrm{g} \cdot \mathrm{min}^{-1}$ and 20 , 40 , and $80 \mu \mathrm{g} \cdot \mathrm{min}^{-1}$, respectively, and the changes in $\mathrm{CBF}$ were evaluated. The doses for ACh and SNP were chosen on the basis of preliminary studies demonstrating that these doses caused significant stepwise increases in $\mathrm{CBF}$ without altering systemic hemodynamic parameters. Following ANH, this drug infusion protocol was repeated to a hematocrit $50 \%$ of baseline, as described for Series 1 above. The range of the intracoronary infusion rates for the SNP and ACh solutions was $0.125-1.0 \mathrm{~mL} \cdot \mathrm{min}^{-1}$. Preliminary studies showed that infusion of the saline vehicle at these rates had no effect on $\mathrm{CBF}$ or related parameters.

The higher level of $\mathrm{CBF}$ and the pre-existing vasodilation during $\mathrm{ANH}$ are factors which could have attenuated the coronary vasodilating effects of ACh and SNP. ${ }^{19}$ To address this possibility, with CBF increased to a level comparable to that during $\mathrm{ANH}$ 
TABLE I Effect of acute normovolemic hemodilution on myocardial blood flow and hemodynamic variables in Series 1. In Group 1, left anterior descending coronary artery bed was selectively treated with L-NAME

\begin{tabular}{|c|c|c|c|c|c|}
\hline & \multicolumn{3}{|c|}{$\begin{array}{c}\text { Group 1 } \\
\text { (NOS inbibition) }\end{array}$} & \multicolumn{2}{|c|}{$\begin{array}{c}\text { Group } 2 \\
\text { (intact endothelium) }\end{array}$} \\
\hline & Baseline & Post L-NAME & ANH & Baseline & $\mathrm{ANH}$ \\
\hline MBF-LAD $\left(\mathrm{mL} \cdot \mathrm{min}^{-1} \cdot 100 \mathrm{~g}^{-1}\right)$ & $82 \pm 25$ & $82 \pm 27$ & $194 \pm 91^{*}$ & $78 \pm 22$ & $191 \pm 61^{*}$ \\
\hline $\operatorname{MBF}-\mathrm{CX}\left(\mathrm{mL} \cdot \mathrm{min}^{-1} \cdot 100 \mathrm{~g}^{-1}\right)$ & $74 \pm 27$ & $73 \pm 29$ & $185 \pm 88^{*}$ & $75 \pm 22$ & $193 \pm 51^{*}$ \\
\hline $\mathrm{MAP}(\mathrm{mmHg})$ & $102 \pm 10$ & $98 \pm 7$ & $100 \pm 10$ & $108 \pm 15$ & $106 \pm 20$ \\
\hline $\mathrm{HR}$ (beats. $\mathrm{min}^{-1}$ ) & $137 \pm 34$ & $141 \pm 32$ & $164 \pm 31^{*} \dagger$ & $134 \pm 42$ & $169 \pm 32 *$ \\
\hline $\operatorname{HCT}(\%)$ & $41 \pm 5$ & $42 \pm 2$ & $20 \pm 2^{*} \dagger$ & $43 \pm 5$ & $20 \pm 2^{*}$ \\
\hline Arterial $\mathrm{pH}$ & $7.39 \pm 0.05$ & $7.39 \pm 0.05$ & $7.35 \pm 0.05$ & $7.42 \pm 0.05$ & $7.37 \pm 0.02$ \\
\hline Arterial $\mathrm{PO}_{2}(\mathrm{mmHg})$ & $299 \pm 169$ & $274 \pm 132$ & $277 \pm 174$ & $382 \pm 115$ & $348 \pm 135$ \\
\hline Arterial $\mathrm{PCO}_{2}(\mathrm{mmHg})$ & $38 \pm 5$ & $40 \pm 5$ & $43 \pm 5$ & $36 \pm 5$ & $37 \pm 2$ \\
\hline
\end{tabular}

Values are mean $\pm \mathrm{SD} . P<0.05,{ }^{*}$ ps baseline, $\dagger$ vs L-NAME. L-NAME $=\mathrm{N}^{\mathrm{G}}$-nitro-L-arginine methyl ester; NOS $=$ nitric oxide synthase; $\mathrm{ANH}=$ acute normovolemic hemodilution; $\mathrm{LAD}=$ left anterior descending artery bed; $\mathrm{CX}=$ circumflex artery bed; $\mathrm{MBF}=$ myocardial blood flow; $\mathrm{MAP}=$ mean artic pressure; $\mathrm{HR}=$ heart rate; $\mathrm{HCT}=$ hematocrit.

(approximately double baseline CBF), we assessed the relationship between the ACh and SNP doses and $\mathrm{CBF}$, a second time prior to inducing $\mathrm{ANH}$. This was accomplished with a submaximal intracoronary infusion of adenosine $\left(6.25 \mu \mathrm{g} \cdot \mathrm{min}^{-1}\right)$.

In each heart preparation in Series 2, adenosine was also infused into the LAD during $\mathrm{ANH}$, for a second time at a rate sufficient to raise CBF maximally. These data were obtained to ensure that the increases in $\mathrm{CBF}$, caused by ACh and SNP during ANH, were not limited by the vasodilator reserve of the preparation.

\section{Radioactive microsphere technique}

Myocardial blood flow was measured with microspheres $(15 \pm 3 \mu \mathrm{m}$ in diameter) and labelled with the $\gamma$-emitting radionuclides, ${ }^{141} \mathrm{Ce},{ }^{51} \mathrm{Cr},{ }^{46} \mathrm{Sc},{ }^{85} \mathrm{Sr}$, and ${ }^{113} \mathrm{Sn}$ (New England Nuclear Corp.). ${ }^{20}$ Beginning simultaneously with each microsphere injection, duplicate reference blood samples were collected at a rate of $6 \mathrm{~mL} \cdot \mathrm{min}^{-1}$ for three minutes, through two cannulas of different lengths threaded into the arch of the aorta via the right femoral artery. Radioactivities of the duplicate reference samples differed by less than $10 \%$, indicating thorough mixing of the microspheres in the left ventricular output. Autologous blood was infused into the dog to compensate for the withdrawn reference samples.

After the final injection of microspheres, the heart was stopped by intravenous injection of potassium chloride, excised, and frozen to facilitate sampling. Samples of myocardium were obtained from the $\mathrm{LAD}$ and CX regions. The tissue and reference blood samples were weighed and analyzed for radioactivity with a gamma scintillation counter equipped with a multichannel analyzer (model 1282-002, LKB, Turku, Finland). Isotope separation was accomplished by standard techniques of $\gamma$-spectroscopy. Values for MBF (in $\mathrm{mL} \cdot \mathrm{min}^{-1} \cdot 100 \mathrm{~g}^{1}$ ) were calculated from the equation:

$$
M B F=A B F \times(M C / A C) \times 100
$$

where $\mathrm{ABF}$ is the rate of arterial reference sampling $\left(\mathrm{mL} \cdot \mathrm{min}^{-1}\right), \mathrm{MC}$ is microsphere radioactivity (counts $\cdot \min ^{-1} \cdot \mathrm{g}^{-1}$ ) in the tissue samples, and $\mathrm{AC}$ is the total microsphere radioactivity (counts $\mathrm{min}^{-1}$ ) in the arterial reference samples.

\section{Statistical analysis}

In Series 1, statistical analysis of changes in MBF and associated hemodynamic variables (Table I) was performed in Group 1, with an analysis of variance for repeated measurements in conjunction with the Student-Newman-Keuls test, ${ }^{21}$ and in Group 2, with the Student's $t$ test for paired samples. ${ }^{21}$ During ANH in Groups 1 and 2 of Series 1 , the Student's $t$ test for paired samples was used to compare the percentage changes in MBF within the LAD and CX regions. The Student's $t$ test for paired samples was also used in Group 1 of Series 1 to assess: 1) the effect of ANH on the coronary vasodilator reserve ratio; and 2) the effect of L-NAME on the CBF increases during $\mathrm{ACh}$ and SNP. An analysis of variance for repeated measurements in conjunction with the Student-Newman-Keuls test was used for all statistical analysis in Series 2. All data are presented as mean \pm SD. A $P<0.05$ was considered significant.

\section{Results}

Series 1

Findings for Series 1 are summarized in Table I. In Group 1, with hematocrit at the baseline level, infu- 
TABLE II Effect of submaximal adenosine and acute normovolemic hemodilution on coronary blood flow and hemodynamic variables in Series 2

\begin{tabular}{llll}
\hline & Baseline & $\begin{array}{l}\text { Adenosine } \\
\text { (submaximal) }\end{array}$ & ANH \\
\hline $\mathrm{CBF}\left(\mathrm{mL} \cdot \mathrm{min}^{-1}\right)$ & $44 \pm 8$ & $101 \pm 13^{*}$ & $78 \pm 7^{*} \dagger$ \\
$\mathrm{MAP}(\mathrm{mmHg})$ & $74 \pm 9$ & $80 \pm 6$ & $83 \pm 11$ \\
$\mathrm{HR}\left(\mathrm{beats} \cdot \mathrm{min}^{-1}\right)$ & $143 \pm 7$ & $138 \pm 3$ & $159 \pm 5^{*} \dagger$ \\
$\mathrm{HCT}(\%)$ & $33 \pm 2$ & $33 \pm 2$ & $15 \pm 2^{*} \dagger$ \\
Arterial pH & $7.42 \pm 0.03$ & $7.39 \pm 0.01$ & $7.42 \pm 0.03$ \\
Arterial $\mathrm{PO}_{2}(\mathrm{mmHg})$ & $281 \pm 43$ & $289 \pm 44$ & $324 \pm 60$ \\
Arterial $\mathrm{PCO}_{2}(\mathrm{mmHg})$ & $35 \pm 3$ & $35 \pm 1$ & $35 \pm 2$
\end{tabular}

Values are mean \pm SD. $P<0.05,{ }^{*} v s$ baseline, $\dagger v s$ adenosine. $\mathrm{ANH}=$ acute normovolemic hemodilution; $\mathrm{CBF}=$ coronary blood flow; $\mathrm{MAP}=$ mean aortic pressure; $\mathrm{HR}=$ heart rate; $\mathrm{HCT}=$ hematocrit.

sion of L-NAME into the LAD had no effect on MBF in the LAD or CX regions, or on systemic hemodynamic or arterial blood variables. Acute normovolemic hemodilution (a reduction in hematocrit from $42 \pm$ $2 \%$ to $20 \pm 2 \%$ ) caused similar, greater than twofold increases in MBF in the LAD (L-NAME treated) and CX (intact endothelial function) beds $(P<0.01)$. Hemodynamic and arterial blood variables were not affected, with the exception that heart rate increased by $+16 \%(P<0.05)$. In Group 2 , ANH caused comparable increases in MBF in the LAD and CX vascular beds $(P<0.01)$, neither of which was treated with $\mathrm{L}^{-}$ NAME. As in Group 1, ANH had no effect on arterial blood gas values or systemic hemodynamic variables, and heart rate increased modestly $(P<0.05)$. Acute normovolemic hemodilution caused a decrease in the coronary vasodilator reserve ratio from $4.2 \pm 0.1$ to $2.1 \pm 0.4(P<0.01)$.

Figure 1 presents the changes in $\mathrm{CBF}$ by $\mathrm{ACh}$ and $\mathrm{SNP}$, before and after L-NAME, in Group 1. $\mathrm{N}^{\mathrm{G}_{-}}$ nitro-L-arginine methyl ester markedly attenuated the increases in CBF by ACh $(P<0.001)$, whereas it had no effect on the increases in CBF by SNP.

\section{Series 2}

The pre-Ach and pre-SNP control values for CBF and related variables under baseline conditions, submaximal adenosine infusion, and ANH in Series 2 are presented in Table II. There were marked increases in the control values for $\mathrm{CBF}$ during adenosine infusion $(+129 \%)$ and $\mathrm{ANH}(+77 \%)$, relative to the baseline value. Figure 2 demonstrates that both ACh (Panel A) and SNP (Panel B) caused dose-dependent increases in CBF $(P<0.05)$, which were not affected by the background infusion of adenosine or by ANH. During $\mathrm{ANH}$, the maximally dilating infusions of adenosine caused increases in CBF of $193 \pm 51 \mathrm{~mL} \cdot \mathrm{min}^{-1}$, which

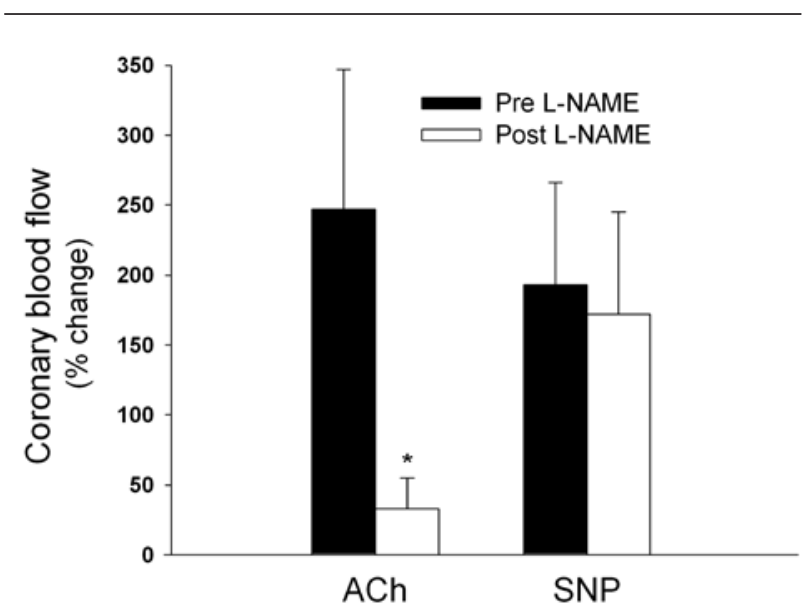

FIGURE 1 Effects of acetylcholine (ACh) and sodium nitroprusside (SNP) on coronary blood flow, before and after $\mathrm{N}^{\mathrm{G}}$-nitro-L-arginine methyl ester (L-NAME). L-NAME blunted the increases in coronary blood flow by ACh, but not by SNP. Values are mean $\pm \mathrm{SD} .{ }^{*} P<0.05$ vs before L-NAME.

greatly exceeded those caused by the infusions of ACh or SNP $(P<0.05)$.

\section{Discussion}

The myocardium has a limited anaerobic capacity, and, if the oxygen supply is compromised, myocardial contraction will weaken or even cease. Under baseline conditions, the left ventricle extracts approximately $75 \%$ of the oxygen that is delivered to it; thus, it has a limited oxygen extraction reserve. ${ }^{17,22,23}$ Consequently, to offset the induced decreases in arterial oxygen content, the myocardium is critically dependent on increases in $\mathrm{CBF}$ during ANH. Previous findings from our laboratory have demonstrated a remarkable capacity of the coronary circulation to increase its blood flow during $\mathrm{ANH}$, as needed to maintain myocardial oxygen supply and contractile function. ${ }^{17,18}$ Whereas previous studies have suggested a role for reduced viscosity in this response, ${ }^{24,25}$ the finding of diminished coronary reactive hyperemic responses shown previously, ${ }^{17,18}$ and confirmed herein, implies that coronary vasodilation is also prominently involved.

The findings in Group 1 from Series 1 indicated parallel increases in MBF in the L-NAME-treated (LAD) and control (CX) vascular beds during ANH. In light of the similar increases in MBF in the two beds, when neither was treated with L-NAME (Group 2 of Series 1), the findings in Group 1 suggest that $\mathrm{NO}$ was not the mediator of coronary vasodilation during ANH. An implication of this finding is that, under baseline conditions, hemoglobin contained within the RBCs did not limit NO bioavailability and 

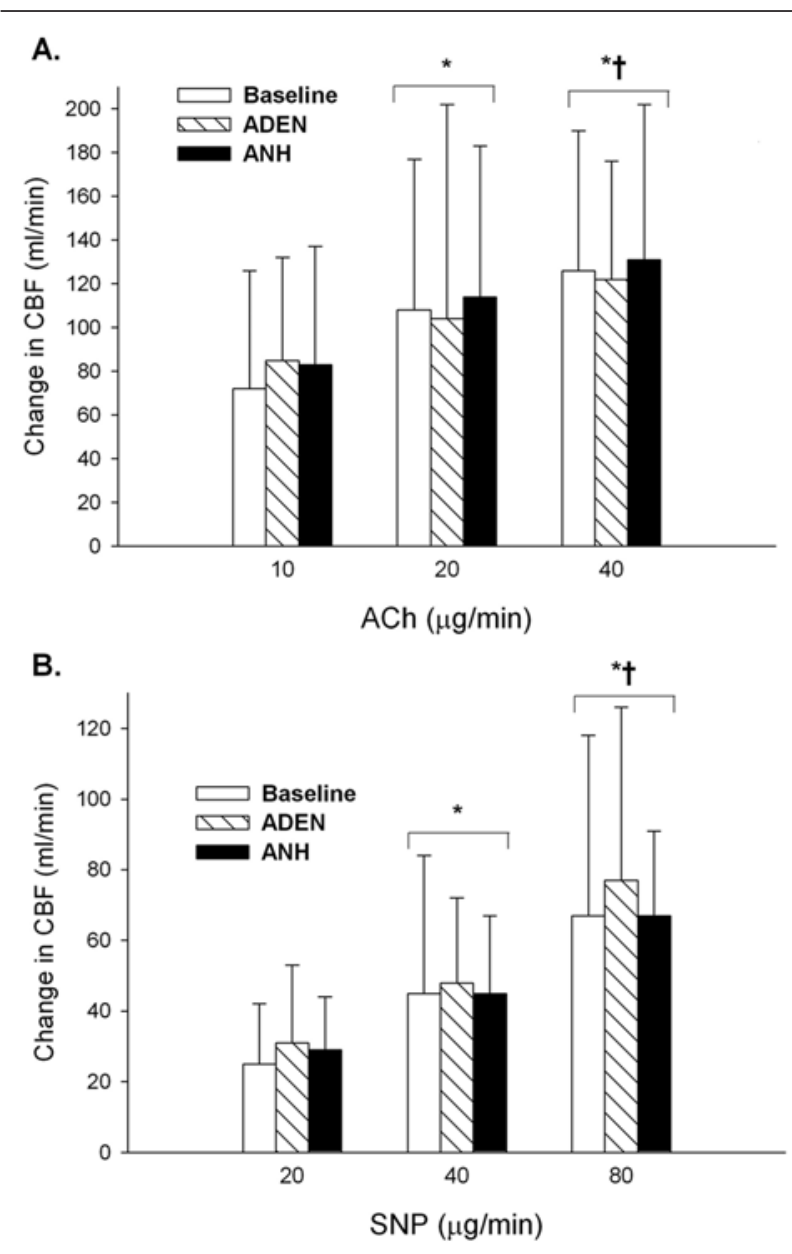

FIGURE 2 The lack of effect of submaximal infusion of adenosine or acute normovolemic hemodilution $(\mathrm{ANH})$ on the dose-dependent increases in coronary blood flow (CBF) caused by acetylcholine $(\mathrm{ACh})$ or sodium nitroprusside (SNP). Values are mean \pm SD. $P<0.05,{ }^{*} v s$ lowest dose; $† v s$ intermediate dose.

the coronary vasodilation resulting from tonic release of NO from the coronary vascular endothelium. If it did, one would have expected an NO-mediated vasodilator effect during $\mathrm{ANH}$, because of reduced $\mathrm{NO}$ scavenging.

An additional potential mechanism for an increased NO availability in the coronary circulation during $\mathrm{ANH}$ is an enhanced release of $\mathrm{NO}$ from the endothelium, because of an increased shear stress. ${ }^{2}$ The lack of effect of L-NAME on the increases in MBF during ANH suggests that this mechanism was not operative in the coronary circulation. Apparently, the tendency for an increased flow velocity to increase shear stress was negated by the combined influence of reduced blood viscosity and vessel dilation.

Intravenous influsions of NOS inhibitors cause increases in systemic vascular resistance (and concomi- tant increases in arterial pressure and left ventricular afterload), ${ }^{3,26}$ suggesting that tonic release of NO may play a role in modulating basal vascular tone in the peripheral circulation. In the present study, the use of selective intracoronary infusions of L-NAME avoided its systemic effects and, thus, simplified interpretation of the changes in MBF. The almost complete elimination of the increases in CBF by the endotheliumdependent vasodilator $\mathrm{ACh}$, without effect on those by the endothelium-independent vasodilator SNP, provided evidence for the effectiveness of our dose for L-NAME. Previous findings have shown that the NOS inhibiting effect of L-NAME can persist for at least eight hours, ${ }^{27}$ which, of course, greatly exceeded the duration of our dextran-for-blood exchange.

The failure of NOS inhibition to reduce baseline CBF has been demonstrated previously, ${ }^{4,28-30}$ and it has been explained by the emergence of an alternate metabolic mechanism, which preserves myocardial oxygen supply/demand balance when the tonic influence of endogenous nitric oxide is blocked. In support of this view, Kostic and Schrader ${ }^{31}$ reported an augmented release of adenosine from isolated pig hearts following administration of L-NAME.

Previous studies have evaluated the role of $\mathrm{NO}$ in the ANH-related vasodilation in the systemic circulation and in regional circulations other than the myocardium. The findings have been inconsistent. Doss et al. ${ }^{12}$ reported that endothelial $\mathrm{NO}$ was responsible for the systemic vasodilation during ANH in halothaneanesthetized rats, since administration of the NOS inhibitor L-nitroarginine completely reversed the ANH-related decreases in total peripheral resistance. On the other hand, Hirose et al. ${ }^{13}$ found that ANH had similar effects on systemic hemodynamic variables, e.g., aortic pressure and systemic vascular resistance, following L-NAME, as it did following phenylephrine (which raised baseline arterial pressure to the same degree as L-NAME without affecting NO production). They concluded that NO was not a key mediator or modulator of the systemic vasodilation during ANH. Todd et al. ${ }^{14}$ showed in anesthetized rabbits, and Plochl et al. ${ }^{15}$ demonstrated in anesthetized dogs that L-NAME had no effect on the increases in cerebral blood flow during $\mathrm{ANH}$, which implied that $\mathrm{NO}$ played no role in these responses. But Panes et al. ${ }^{11}$ reported that another NOS inhibitor, $\mathrm{N}^{\mathrm{G}}$-monomethyl-L-arginine, diminished the increases in gastric blood flow in a rat model of ANH, which suggested that these increases in blood flow were dependent on endogenous formation of NO. The differing experimental models, protocols, and endpoints, make it difficult to formulate general conclusions concerning 
the role of endothelial $\mathrm{NO}$ in the vascular relaxation during $\mathrm{ANH}$. The findings, to date, suggest that the regulatory role of endothelial $\mathrm{NO}$ during $\mathrm{ANH}$ may be regionally heterogeneous, e.g., gastrointestinal tract greater than the so-called vital organs (heart and brain), but this requires confirmation under well-controlled and standardized experimental conditions.

The focus of our study was the NO released via the action of endothelial NO synthase. However, it is known that neuronal NOS is also present in the heart within the perivascular cardiac nerves, ${ }^{32}$ albeit at lower levels than endothelial NOS. ${ }^{33}$ Since L-NAME is a non-selective NO synthase inhibitor, ${ }^{34}$ its lack of effect on the ANH-induced increases in MBF implies that neither isoform of NOS played a role in these responses.

The factor(s) mediating coronary vasodilation during $\mathrm{ANH}$ remain to be clarified. Since the increases in $\mathrm{MBF}$ during $\mathrm{ANH}$ have been shown to be just sufficient to maintain coronary venous $\mathrm{PO}_{2}$ (and presumably myocardial $\mathrm{PO}_{2}$ ) constant, ${ }^{17,18}$ a factor that is coupled to myocardial oxygen metabolism seems probable. Potential candidates include adenosine released from the cardiomyocytes ${ }^{23}$ and an opening of the adenosine triphosphate-sensitive potassium channels in vascular smooth muscle. ${ }^{35}$

The findings in Series 1 (as well as in Series 2) pertain strictly to the specific conditions of our study. We cannot rule out different results, if a more severe level of ANH were studied, or if a diluent with a different viscosity or ionic composition from dextran were used. Moreover, although ANH has been demonstrated to increase MBF in other species, including humans, ${ }^{36}$ it cannot be assumed that the mechanism(s) responsible for this effect are similar. Thus, care must be exercised in extrapolating our findings to the clinical situation. Although the present findings suggest that ANHrelated increases in MBF would be well preserved in patients with endothelial dysfunction, e.g., due to atherosclerosis, reperfusion injury, or denudation associated with balloon catheter interventions, this requires experimental confirmation.

Our findings in Series 2 indicated similar doserelated increases in $\mathrm{CBF}$ by $\mathrm{ACh}$ and SNP, before and following ANH. This suggested that scavenging by hemoglobin contained in RBCs did not limit the bioavailabilty of $\mathrm{NO}$ released by the endothelium or supplied by a pharmacological donor. A potential complicating factor in Series 2 was the higher level of $\mathrm{CBF}$ (and pre-existent vasodilation) following $\mathrm{ANH}$, which, in theory, could have blunted pharmacologically-induced coronary vasodilation. ${ }^{19}$ However, this possibility appears unlikely, since the responses to
ACh and SNP were similar when CBF was increased to an even slightly higher level with adenosine, while hematocrit was not changed. The higher flows during the maximally-dilating infusions of adenosine indicated that the ACh- and SNP-induced increases in CBF following $\mathrm{ANH}$ were not limited by the vasodilator reserve of the preparation.

In summary, our study suggested that endothelial NO does not mediate the coronary vasodilation accompanying $\mathrm{ANH}$, and $\mathrm{ANH}$ does not affect the coronary vasodilating effects of endothelial or exogenous NO.

\section{References}

1 Moncada S, Palmer RM, Higgs EA. Nitric oxide: physiology, pathophysiology, and pharmacology. Pharmacol Rev 1991; 43: 109-42.

2 Bassenge E, Busse R. Endothelial modulation of coronary tone. Prog Cardiovasc Dis 1988; 30: 349-80.

3 Crystal GJ, Zhou X, Halim AA, Alam S, El-Orbany M, Salem $M R$. Nitric oxide does not modulate whole body oxygen consumption in anesthetized dogs.

J Appl Physiol 1999; 86: 1944-9.

4 Crystal GJ, Gurevicius J. Nitric oxide does not modulate myocardial contractility acutely in in situ canine hearts. Am J Physiol 1996; 270: H1568-76.

5 Crystal GJ, Zhou X, Alam S, Piotrowski A, Hu G. Lack of role for nitric oxide in cholinergic modulation of myocardial contractility in vivo. Am J Physiol Heart Circ Physiol 2001; 281: H198-206.

6 Azarov I, Huang KT, Basu S, Gladwin MT, Hogg N, Kim-Shapiro DB. Nitric oxide scavenging by red blood cells as a function of hematocrit and oxygenation. J Biol Chem 2005; 280: 39024-32.

7 Huang KT, Han TH, Hyduke DR, et al. Modulation of nitric oxide bioavailability by erythrocytes. Proc Natl Acad Sci USA 2001; 98: 11771-6.

8 Liu X, Miller MJ, Joshi MS, Sadowska-Krowicka H, Clark DA, Lancaster JR Jr. Diffusion-limited reaction of free nitric oxide with erythrocytes. J Biol Chem 1998; 273: 18709-13.

9 Vaughn MW, Huang KT, Kuo L, Liao JC. Erythrocyte consumption of nitric oxide: competition experiment and model analysis. Nitric Oxide 2001; 5: 18-31.

10 Anand IS, Chandrashekhar $\Upsilon$, Wander GS, Chawla $L S$. Endothelium-derived relaxing factor is important in mediating the high output state in chronic severe anemia. J Am Coll Cardiol 1995; 25: 1402-7.

11 Panes J, Casadevall M, Pique JM, Bosch J, Whittle BJ, Teres J. Effects of acute normovolemic anemia on gastric mucosal blood flow in rats: role of nitric oxide. Gastroenterology 1992; 103: 407-13.

12 Doss DN, Estafanous FG, Ferrario CM, Brum JM, 
Murray PA. Mechanism of systemic vasodilation during normovolemic hemodilution. Anesth Analg 1995; 81: 30-4.

13 Hirose $\Upsilon$, Kimura $H$, Kitahata $H$, Kawahito S, Oshita $S$. Nitric oxide does not play a major role in the regulation of systemic hemodynamic responses to acute normovolemic hemodilution. Acta Anaesthesiol Scand 2000; 44: 96-100.

14 Todd MM, Farrell S, Wu B. Cerebral blood flow during hypoxemia and hemodilution in rabbits: different roles for nitric oxide? J Cereb Blood Flow Metab 1997; 17: 1319-25.

15 Plochl W, Liam BL, Cook DJ, Orszulak TA. Cerebral response to haemodilution during cardiopulmonary bypass in dogs: the role of nitric oxide synthase. Br J Anaesth 1999; 82: 237-43.

16 Kazama T, Ikeda K. Comparison of MAC and the rate of rise of alveolar concentration of sevoflurane with halothane and isoflurane in the dog. Anesthesiology 1988; 68: 435-7.

17 Levy PS, Kim SJ, Eckel PK, et al. Limit to cardiac compensation during acute isovolemic hemodilution: influence of coronary stenosis. Am J Physiol 1993; 265: H340-9.

18 Crystal GJ, Kim SJ, Salem MR. Right and left ventricular $\mathrm{O}_{2}$ uptake during hemodilution and beta-adrenergic stimulation. Am J Physiol 1993; 265: H1769-77.

19 Myers HA, Honig CR. Influence of initial resistance on magnitude of response to vasomotor stimuli. Am J Physiol 1969; 216: 1429-36.

20 Crystal GJ, Salem MR. Myocardial and systemic hemodynamics during isovolemic hemodilution alone and combined with nitroprusside-induced controlled hypotension. Anesth Analg 1991; 72: 227-37.

21 Glantz $S A$, Slinker BK. Primer of applied regression and analysis of variance. New York: McGraw-Hill Inc.; 1990.

22 Crystal GJ, Rooney MW, Salem MR. Regional hemodynamics and oxygen supply during isovolemic hemodilution alone and in combination with adenosine-induced controlled hypotension. Anesth Analg 1988; 67: 211-8.

23 Feigl EO. Coronary physiology. Physiol Rev 1983; 63: 1-205.

24 Crystal GJ. Coronary hemodynamic responses during local hemodilution in canine hearts. Am J Physiol 1988; 254: H525-31.

25 Holtz J, Bassenge E, von Restoriff W, Mayer E. Transmural differences in myocardial blood flow and in coronary dilatory capacity in hemodiluted conscious dogs. Basic Res Cardiol 1976; 71: 36-46.

26 Kaufmann PA, Rimoldi OE, Gnecchi-Ruscone T, Luscher TF, Camici PG. Systemic nitric oxide synthase inhibition improves coronary flow reserve to adenosine in patients with significant stenoses. Am J Physiol Heart Circ Physiol 2007; 293: H2178-82.

27 Perez AC, Khawaja AM, Page CP, Paul W. Persistence of effects of nitric oxide synthase inhibitors: comparisons on blood flow and plasma exudation in guinea pig skin. Eur J Pharmacol 1997; 330: 241-6.

28 Kaneko H, Endo T, Kiuchi K, Hayakawa H. Inhibition of nitric oxide synthesis reduces coronary blood flow response but does not increase cardiac contractile response to beta-adrenergic stimulation in normal dogs. J Cardiovasc Pharmacol 1996; 27: 247-54.

29 Parent $R$, al-Obaidi $M$, Lavallee $M$. Nitric oxide formation contributes to beta-adrenergic dilation of resistance coronary vessels in conscious dogs. Circ Res 1993; 73: 241-51.

30 Saeki A, Recchia FA, Senzaki H, Kass DA. Minimal role of nitric oxide in basal coronary flow regulation and cardiac energetics of blood-perfused isolated canine heart. J Physiol 1996; 491(Pt 2): 455-63.

31 Kostic MM, Schrader J. Role of nitric oxide in reactive hyperemia of the guinea pig heart. Circ Res 1992; 70: 208-12.

32 Klimaschewski L, Kummer W, Mayer B, et al. Nitric oxide synthase in cardiac nerve fibers and neurons of rat and guinea pig heart. Circ Res 1992; 71: 1533-7.

33 Brahmajothi MV, Campbell DL. Heterogeneous basal expression of nitric oxide synthase and superoxide dismutase isoforms in mammalian heart: implications for mechanisms governing indirect and direct nitric oxide-related effects. Circ Res 1999; 85: 575-87.

34 Moove PK, Handy RL. Selective inhibitors of neuronal nitric oxide synthase--is no NOS really good NOS for the nervous system? Trends Pharmacol Sci 1997; 18: 204-11.

35 Nelson MT. Regulation of arterial tone by potassium channels. Jpn J Pharmacol 1992; 58 Suppl 2: 238P-42P.

36 Spahn DR, Leone BJ, Reves JG, Pasch T. Cardiovascular and coronary physiology of acute isovolemic hemodilution: a review of nonoxygen-carrying and oxygencarrying solutions. Anesth Analg 1994; 78: 1000-21. 